\title{
Assessment of some groundwater wells in the west of Al Najaf city for by Water Quality Index (WQI)
}

\author{
Rand Sami Kamel \\ University of Babylon, College of Science \\ Randalsalami82@gmail.com_kamal.mauff@gmail.com
}

\author{
Ahmed Abbas Hassan
}

ahmedalgeology@gmail.com

\section{Received:- $10 / 5 / 2017$}

Accepted:-13/7/2017

\begin{abstract}
Najaf an Iraqi city considered an agricultural city. Located southwest of Baghdad this study was conducted for the purpose of evaluating the quality of well water in the South and West of Najaf through chose 32 a water well distributed in the region and analyzed chemically and physically. The results showed a variation of water quality in different locations. The test for validity of water for agricultural use it found that the electric conductivity EC ranged between (5305-2342) disisimnz-1 in Wells 6, 7, 9, 12, 13, 14, 16, 17, 21, 22, 26, 28, 30, 31,32 , where there is a clear increase in the values of electrical conductivity. Electrical conductivity values depend on the concentration of water and the quality of its salts, the SAR values ranging from (6812-0.92), so that the classification of these wells according to the specifications of the agriculture and food Organization to determine the validity of the irrigation water was as follows: it was a very large TDS values exceeded the limits of risk of irrigation by this specification, the influence of sodium adsorption ratio SAR with EC electrical conductivity with impact (few-average) on agricultural crops , Na sodium values ranging from (51-1000) ppm so there is no impact on agricultural crops, $\mathrm{Cl}$ values ranging from (117-1375) ppm and bicarbonate ion HCO3 ranged between (58.507) ppm so it's not any problem when irrigation with this specification. The value of nitrates NO3 ranging from (3-700) ppm where the wells are 13, 15, 17, 30, NO3 ratio greater than 30 and that's very dangerous when irrigation with NO3. Either the wells 2 s this range is allowed except wells number 22, 23, 32 , were lower than the limits allowed by the specification.

The results shows that the water is not safe for drinking and need to use treatment for animal handlers and agricultural crops
\end{abstract}

Keywords: WQI, ground water, wells, physicochemical factors 


\subsection{Introduction}

Water resources are of central importance for agriculture and industry in the world as well as their importance to man of drinking and daily uses. Leading to the use of alternatives of fresh water that are poor water and drainage water and industrial sewage and that may be used for agriculture or industry [15]. And for the purpose of drinking water use must have properties and characteristics have been adopted by the World Health Organization WHO as directory standards and parameters for drinking water [16], and followed by the countries of the world and every country has its own guide according to the quality of water in that country [2], The first purification of groundwater begins through the soil, where the soil is a pored media adaptability natural filtration of water, the previous studies has lime and in turn transmitted with irrigation water

\section{1 -materials and methods}

[11].

The study of examined water quality in many countries are the most important quality standards for irrigation water that must be studied and most agreed [5]. The US Agriculture Department recorded in his USDA of 1954 [14]. The most important specification characteristics of water quality is the value and sodium adsorption ratio electric conductivity and boron concentration and bicarbonate. Both the food and Agriculture Organization of the United Nations FAO [11], have adopted electric conductivity value direct impact on plant growth and sodium adsorption ratio of that impact on soil permeability and concentrations of chlorine, boron and sodium as a harmful ions and adopted other incidental effects such as nitrate and bicarbonate and the degree of interaction of water. Either the last Organization for 1992, [20gillli], has adopted the salt concentration estimated with electric conductivity to determine the type of salt water demonstrated that the maximum depth reached pollutants are within 2 meters from the ground surface [8], The criteria and the validity of drinking water parameters are divided into three criteria physicist and chemist and biological. Physical properties include temperature suspended solids-color - taste and smell. Either chemical properties are $\mathrm{pH}$ - Hardness Turbidity and unwanted elements. While biological properties divided into two types: viral and bacterial indicators and check for bacteria only in water because the virus needs a living body for reproduction and transmission [1], [16], to assess water quality for irrigation and livestock dependent on several criteria, the most important one is the total content of salts, and ion composition significantly that resulting variation in quality terms depend on the type

and quantity of dissolved salts and from melting or weathering rocks like dissolving gypsum and and came up with six varieties and types of salt water. While [19], classified the water into six classes depending on the sodium adsorption ratio and outreach and boron ion concentration and effectiveness of chloride ion and proposed a guide to rating the quality of irrigation water for Iraqi waters.

The scope of this study is to test the validity of water for human drinking purposes by using WQI the validity for Animals and Agricultural use.

The study adopted to collect samples from 32 a wells have been drilled in the South and southern west of Najaf depths ranged between (15-45) meters, and took water samples from these wells used sterile plastic bottles capacity $(100 \mathrm{~cm} 3)$ for the collection and preservation of samples and conducted by the following tests:

Ionic chemical estimates: measured the degree of interaction $\mathrm{PH}$ and electrical conductivity EC assessment and positive and negative ions are 
dissolved in accordance with the methods described in [14]. Estimated total materials TDS (TDS) Total Dissolved Solids of uniform drying method [1], [16],[2], Samples were saved during the stages of analysis at $4^{\circ} \mathrm{c}$ for the purpose of keeping them from evaporation and biological processes

\section{1-1 Description of study site}

Najaf lies south of Baghdad $(163 \mathrm{Km})$. Samples collected from wells distributed in the study area, the wells widespread in different regions in Najaf. (Table 1 , and figure 1).

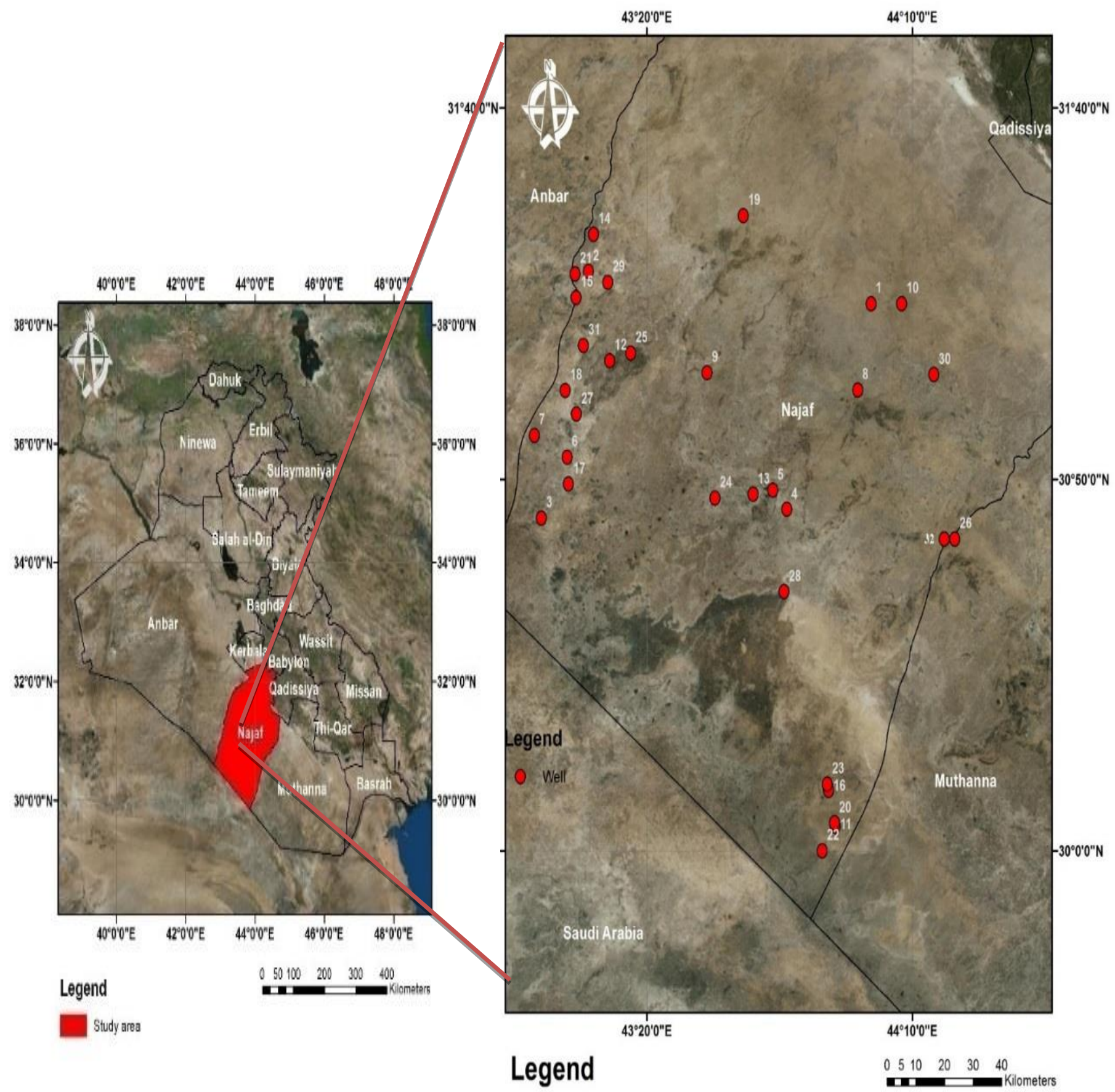

- Well 
Figure (1) Wells location of the study area

Table (1) Coordinates of Wells

\begin{tabular}{|c|c|c|c|c|}
\hline No.Well & Locality & LAT_DEC & LONG_DEC & Elevation \\
\hline 1 & BAHER NAJAF & 31.227778 & 44.0375 & 298 \\
\hline 2 & AL AAZIYA1 & 31.3 & 43.15 & 281 \\
\hline 3 & AL MAANIYA1 & 30.746667 & 43.002778 & 308 \\
\hline 4 & AL SEHEL 2 & 30.783333 & 43.75 & 323 \\
\hline 5 & ALSHABICHA4 & 30.800833 & 43.7325 & 294 \\
\hline 6 & SAIGALSD3 & 30.883333 & 43.083333 & 319 \\
\hline 7 & RUM-HAD K385 & 31.089167 & 42.925278 & 281 \\
\hline 8 & GREENBELTI & 31.034167 & 43.995 & 254 \\
\hline 9 & RUM-HADK318 & 31.073056 & 43.522778 & 278 \\
\hline 10 & AIN MISTRAHA & 31.227778 & 44.133333 & 386 \\
\hline 11 & UMM MANAJEF1 & 30.066667 & 43.916667 & 409 \\
\hline 12 & AMERYNAJAF6 & 31.1 & 43.216667 & 281 \\
\hline 13 & KAR -NAJRO20 & 30.8 & 43.666667 & 296 \\
\hline 14 & AL-SAADIYA1 & 31.383333 & 43.166667 & 281 \\
\hline 15 & UMMASEI & 31.279167 & 43.114167 & 317 \\
\hline 16 & KER NAJ.RO58 & 30.15 & 43.9 & 409 \\
\hline 17 & OIL PUMPST3 & 30.823056 & 43.087778 & 50 \\
\hline 18 & JDEIDA 1 & 31.033333 & 43.076944 & 277 \\
\hline 19 & AL RUHIMA 1 & 31.425278 & 43.636389 & 294 \\
\hline 20 & KHALIJARAD2 & 30.066667 & 43.916667 & 386 \\
\hline 21 & KAR-NAJRO 24 & 31.3 & 43.116667 & 324 \\
\hline 22 & JAMILIYA 3 & 30 & 43.883333 & 259 \\
\hline 23 & KHAN HAAMAD & 30.15 & 43.9 & 386 \\
\hline 24 & AL JAMAIYA 1 & 30.791389 & 43.547222 & 316 \\
\hline 25 & ALJUMILIYA2 & 31.116667 & 43.283333 & 317 \\
\hline 26 & MADHLODM V.8 & 30.7 & 44.3 & 277 \\
\hline 27 & SAIGAL2 & 30.979722 & 43.112222 & 281 \\
\hline 28 & BRAGAHAMAD4 & 30.581389 & 43.764167 & 194 \\
\hline 29 & SUMMELI 2 & 31.275833 & 43.211111 & 277 \\
\hline 30 & MAANIYA 4 & 31.068333 & 44.233889 & 291 \\
\hline 31 & $\ldots$ & 31.133889 & 43.134167 & 295 \\
\hline 32 & SONA 2 & 30.7 & 44.266667 & 31 \\
\hline
\end{tabular}




\section{1-2 Geology of the Study Area:}

The study area is located within the Inner Platform and the Outer Platform of the Arabian Plate [17], [18]. The contact between the two platforms passes in the apex area of the fan. Consequently, the two cliffs are located within the Outer Platform represented by the Mesopotamia Foredeep, its western margins, whereas, the extreme part of the studied area is located within the Inner Platform [17], no surface faults occur near the two cliffs. However, the Abu Jir-Euphrates Fault Zone passes in the western part of the studied area. The presence of tens of springs is good indication for this active tectonic zone.

The exposed geological formations and present Quaternary sediments are briefly mentioned, hereinafter.

\section{Dammam Formation, Upper Member (Late Eocene)}

Only the upper member of the Dammam Formation is exposed in the studied area. The upper member consists of thickly bedded limestone: some beds include small nummulites, with marl intercalations and very rare chert lenses.

\section{Euphrates Formation (Early Miocene)}

The formation consists of basal conglomerate and/or breccia, followed upwards by fossiliferous limestone, dolostone with some marl intercalations. The pebbles of the conglomerate are derived from the underlying Dammam Formation, the size of the pebbles ranges from $<0.1 \sim 1.5 \mathrm{~m}$.

Nfayil Formation, Lower Member (Middle Miocene)

Only the lower member of the Nfayil Formation is exposed in the studied area. The upper member consists of three sedimentary cycles. Each cycle consists of green marl overlain by limestone. The limestone of the second cycle includes large oyster shells.

\section{Dibdibba Formation (Pliocene-Pleistocene)}

The formation consists of coarse and white sandstone and rare conglomerate.

Quaternary Sediments
Different types of Quaternary sediments are eveloped in the studied area, like gypcrete, sabkha, sand dunes, alluvial fan, flood plain, depression fill, and valley fill sediments. However, the gypsum is the most widely developed and covers the majority of the Karbala-Najaf Alluvial Fan. The fan is originated from Al-Khir Valley. Its length is 64 $\mathrm{km}$ with SW-NE trend. The size of the gravels of the fan ranges from $1 \sim 2 \mathrm{~cm}$,

\section{1-3 results and discussion}

Result for completing the laboratory tests of samples taken from wells table (2), it can test the validity of water for human, animal and agriculture consumption and. For testing the validity of human drinking water: WQI is calculated for each well as follows:

$\mathrm{WQI}=\Sigma(\mathrm{Ci} / \mathrm{Si}) / \mathrm{n}$

Where:

$\mathrm{Ci}=$ Concentration of each component in the form in $(\mathrm{mg} / \mathrm{L})$.

$\mathrm{Si}=$ Iraqi drinking specification for each element.

$\mathrm{n}=$ Number of elements in the sample.

Table (3) shows the WQI results for each well. And have been compared to Iraq's drinking water specifications table (4) found that all of these wells water not suitable for drinking.

1-Test the validity of water for irrigation crops: it found that the electric conductivity ranged from EC (5305-2342) disisimnz table (2) in Wells 6, 7, 9, 12, 13, 14, 16, 17, 21, 22, 26, 28, $30,31,32$, where there is a clear increase in the values of electrical conductivity. Electrical conductivity values depend on the concentration and type of salts that found in water sample. The reason of high salts concentrations of wells is due to the region's geological composition and effect on water salinity underground water seeps through the 
layers of Earth and acrid its melting salts by force [3],[6]. Classification of Water is depending on the specifications of the World Health Organization WHO, 1989).

So that the classification of these wells depending on the food and Agriculture Organization specification [13], to determine the validity of irrigation water;

3-Very large TDS values were exceeded limits, so there is a risk of irrigation depending on this specification.

4 -Sodium adsorption ratio SAR effect with EC electrical connectivity with impact (fewmoderate) on agricultural crops.

5 -Na sodium values ranging from ppm (511000) so there is no impact on agricultural crops.

$6-\mathrm{Cl}$ ion values ranging from (117-1375) $\mathrm{ppm}$ so that there is no risk recorded. -NO3 nitrate values were ranging from (3-700) $\mathrm{ppm}$ where the wells are $13,15,17,30, \mathrm{NO} 3$ ratio greater than $30 \mathrm{ppm}$ and this very dangerous when irrigation where $\mathrm{NO} 3$ ratio is very high concentration. Either the wells 2, 6, 9, 15, 18, 28,32 , NO3 was between (5-30) ppm and this concentration is medium-low dangerous when
2 -SAR values were ranging from (6812-0.92).

irrigating. While the remaining wells, concentrations of NO3 less than 0.5 so no problem when irrigating.

7 -Bicarbonate ion $\mathrm{HCO} 3$ worth between ppm (58-507) and all samples were less than $15 \mathrm{ppm}$ so there isn't any danger when irrigating.

8 - $\mathrm{pH}$ set by the World Health Organization and the Central Agency for Standardization and Quality Control of drinking water and the U.S. Environmental Protection Agency specifications of 1975, range from 6.5-8.5. And through a table (2) Note that groundwater interaction degree values measured fall within this range except wells number 22, 23, 32, were lower than the limits allowed by these specifications.

Test the validity of water for animal use: TDS values ranging from (4570-658) where the concentration of the total dissolved salts balance for the groundwater in the study area with the classification of [12],[9],. Table (3) is the value of WQI between (2323-387). 
Table (2) the Physical and Chemical Analysis of Water Wells of the Study Area

\begin{tabular}{|c|c|c|c|c|c|c|c|c|c|c|c|c|}
\hline well & SAR & $\mathrm{EC}$ & TDS & ph & $\mathrm{K}$ & $\mathrm{Na}$ & $\mathrm{Mg}$ & $\mathrm{Ca}$ & $\mathrm{Cl}$ & SO4 & $\mathrm{HCO} 3$ & NO3 \\
\hline 1 & 2.367128 & 0 & 2687 & 7.4 & 0 & 239 & 320 & 245 & 1085 & 658 & 258 & 0 \\
\hline 2 & 4.819688 & 0 & 2715 & 8 & 0 & 414 & 213 & 208 & 767 & 999 & 210 & 11 \\
\hline 3 & 2.743349 & 0 & 1943 & 8.2 & 0 & 213 & 157 & 198 & 242 & 1073 & 121 & 0 \\
\hline 4 & 2.592209 & 0 & 4200 & 7.2 & 0 & 336 & 432 & 561 & 0 & 1378 & 507 & 0 \\
\hline 5 & 2.42689 & 0 & 0 & 7.7 & 0 & 82 & 27 & 42 & 0 & 296 & 214 & 0 \\
\hline 6 & 1.569733 & 3700 & 2862 & 6.9 & 0 & 163 & 253 & 400 & 380 & 1590 & 180 & 5 \\
\hline 7 & 6.812003 & 5305 & 3385 & 7.9 & 0 & 607 & 183 & 300 & 1349 & 768 & 146 & 0 \\
\hline 8 & 11.28775 & 0 & 4570 & 7.3 & 0 & 1000 & 180 & 298 & 1200 & 1884 & 140 & 0 \\
\hline 9 & 2.402624 & 2342 & 1827 & 7.8 & 0 & 173 & 117 & 200 & 213 & 960 & 147 & 5 \\
\hline 10 & 4.570305 & 0 & 2023 & 6.8 & 0 & 308 & 102 & 176 & 0 & 605 & 90 & 0 \\
\hline 11 & 4.280743 & 0 & 2619 & 7 & 0 & 368 & 165 & 288 & 724 & 854 & 220 & 0 \\
\hline 12 & 7.295846 & 4950 & 3775 & 7.8 & 0 & 692 & 200 & 352 & 1375 & 1050 & 213 & 0 \\
\hline 13 & 5.812128 & 4760 & 3310 & 8.2 & 0 & 518 & 171 & 320 & 994 & 1090 & 177 & 75 \\
\hline 14 & 1.813485 & 4000 & 2921 & 7.4 & 0 & 184 & 216 & 424 & 450 & 1550 & 75 & 60 \\
\hline 15 & 4.664394 & 0 & 2641 & 7.5 & 0 & 389 & 145 & 288 & 735 & 970 & 220 & 4 \\
\hline 16 & 11.29204 & 4400 & 3085 & 7.5 & 0 & 780 & 98 & 200 & 1207 & 700 & 201 & 700 \\
\hline 17 & 4.221064 & 3500 & 3205 & 7.7 & 0 & 388 & 170 & 360 & 532 & 1560 & 138 & 5 \\
\hline 18 & 4.210658 & 0 & 2465 & 7.3 & 0 & 340 & 125 & 288 & 607 & 883 & 210 & 10 \\
\hline 19 & 3.624346 & 0 & 3111 & 7.9 & 0 & 345 & 169 & 408 & 596 & 1459 & 130 & 4 \\
\hline 20 & 2.316202 & 0 & 2310 & 7.1 & 0 & 196 & 132 & 325 & 210 & 1351 & 197 & 0 \\
\hline 21 & 4.504621 & 5732 & 4479 & 7.9 & 0 & 518 & 239 & 608 & 1065 & 1985 & 58 & 0 \\
\hline 22 & 1.439906 & 2930 & 2613 & 6.4 & 0 & 138 & 165 & 424 & 213 & 1625 & 92 & 3 \\
\hline 23 & 1.438901 & 0 & 3500 & 6.2 & 0 & 150 & 195 & 502 & 1017 & 0 & 145 & 0 \\
\hline 24 & 1.038104 & 0 & 658 & 8.1 & 0 & 51 & 43 & 112 & 117 & 202 & 260 & 0 \\
\hline 25 & 0.920836 & 0 & 2314 & 8 & 0 & 86 & 151 & 412 & 211 & 1416 & 77 & 0 \\
\hline 26 & 3.537275 & 3840 & 2774 & 7.5 & 0 & 315 & 134 & 380 & 604 & 1248 & 73 & 0 \\
\hline 27 & 1.711372 & 0 & 2559 & 8 & 0 & 161 & 149 & 425 & 266 & 1517 & 83 & 0 \\
\hline 28 & 3.814705 & 3963 & 3126 & 6.6 & 0 & 368 & 156 & 448 & 675 & 1200 & 134 & 13 \\
\hline 29 & 2.390722 & 0 & 3072 & 8.2 & 0 & 241 & 165 & 498 & 466 & 1670 & 65 & 0 \\
\hline 30 & 1.899213 & 3686 & 3246 & 7.2 & 0 & 202 & 156 & 600 & 235 & 1946 & 134 & 40 \\
\hline
\end{tabular}


AL-Qadisiyah Journal of pure Science Vol.23 No.2 $\quad$ Year 2018

\begin{tabular}{|l|l|l|l|l|l|l|l|l|l|l|l|l|}
31 & 4.971565 & 4100 & 2655 & 7.3 & 0 & 520 & 60 & 730 & 486 & 700 & 129 & 0 \\
\hline 32 & 1.534614 & 2937 & 2330 & 6 & 0 & 144 & 298 & 176 & 213 & 1437 & 113 & 5 \\
\hline
\end{tabular}

Table (3) Results of WQI for Each Wall

\begin{tabular}{|c|c|}
\hline well no. & WQI \\
\hline 1 & 1580.747619 \\
\hline 2 & 1540.345238 \\
\hline 3 & 1104.835714 \\
\hline 4 & 2094.857143 \\
\hline 5 & 387 \\
\hline 6 & 1592.009524 \\
\hline 7 & 1788.285714 \\
\hline 8 & 2323.809524 \\
\hline 9 & 1015.319048 \\
\hline 10 & 869.0261905 \\
\hline 11 & 1433.257143 \\
\hline 12 & 2031.452381 \\
\hline 13 & 1886.47619 \\
\hline 14 & 1662.052381 \\
\hline 15 & 1473.242857 \\
\hline 16 & 3057.333333 \\
\hline 17 & 1655.5 \\
\hline 18 & 1356.964286 \\
\hline 19 & 1645.492857 \\
\hline 20 & 1275.345238 \\
\hline 21 & 2293.62619 \\
\hline 22 & 1388.502381 \\
\hline 23 & 1406.309524 \\
\hline 24 & 538.6095238 \\
\hline 25 & 1267.138095 \\
\hline 26 & 1450.447619 \\
\hline 27 & 1379.769048 \\
\hline 28 & 1631.409524 \\
\hline 29 & 1624.985714 \\
\hline 30 & 1785.1 \\
\hline 31 & 1554.809524 \\
\hline
\end{tabular}


classifications. Iraqi Journal of agricultural sciences, 13-1: 38(6).

6. - The Iraqi Meteorological and seismological, climate part, climatic data section of Najaf station (unpublished), Baghdad

7. _ The Ministry of water resources.

8._Al Dory, Basim Fadel, The

Water Resources and the Economic Security in the Arab world, $\mathrm{PhD}$ in Economics, College of Management and Economics _ Baghdad University (1994).

9._Altoviski,M.E.,1962.Hand book of hydrogeology, Gosgeolitzdat, Moscow, USSR(in Russian).614p

10._American public helth association(APHA).1998.standard methods for examination of water and wastewater 23ed ed .New York.

11. _Ayers, R.S. and Westcot, D.W., 1985. Water quality for agriculture, Irrigation and Drainage paper 29, Rev.1, FAO, Rome, Italy, 174p. pp.113.

12. _Gorrel, H.A., 1958. Classification of formation waters based on sodium chloride content. Bull. Am. Assoc. Pet. Geol. 42, 2513.

13. _Rhoades, J.D., A. Kandiah and A.M. Mashali. 1992 .The Use of Saline Waters for Crop Production. FAO Irrigation and Drainage Paper 48. Rome, Italy, pp.7-9

14. _Richards, L.A. 1954. Diagnosis and improvement of saline and alkali soils. U.S. Dept. of Agri. Handbook No.60., pp.69-82.

15. _Water Management Studies , Arab Center Department activities in the field of water studies, (1996), Journal of agriculture and water, number 16.
To assessment of some groundwater wells in the west of Al Najaf city for by Water Quality Index( WQI )32 samples were collected from selected site, to comprehensive physico-chemical analysis. For calculating the WQI twelve parameters have been considered such as SAR,EC,TDS,PH,K, $\mathrm{Na}, \mathrm{Mg}, \mathrm{Ca}, \mathrm{Cl}, \mathrm{SO} 4, \mathrm{HCO} 3$ and NO3. The result shows that $90 \%$ of water sample bad water category. Only one site at well 5 limit for drinking water is good. The high value of WQI at this site has been found to be mainly from the higher values of calcium, potassium, nitrate, total dissolved solids, bicarbonate, and chloride in the groundwater

\section{Reference:}

1. - Abbawy, Souad Abd and Mohammed Sulaiman Hassan, 1990, Practical engineering for water tests environment. Al Hikma house for printing and publishing, Musel, Iraq, Page 23, 24, 27, 51, 50, 56, 81, 112 .

2. _ Barakat, Nadia Tarik, 2007, Measurement of contaminants of drinking water in some areas of Baghdad. Master Thesis, collage of science, Baghdad University., p 42.

3. _ _ General Authority for Surveying, topographic maps with scale $1 / 50000$

4. _ Shit, Bassel Mohammed, 2004, Study of chemical variation of some well water for the Eastern Tigris and assess suitability for human use and irrigation, Journal of agricultural sciences.. 35 (2): $1-8$.

5. _ Shkry, Hussein Mahmoud and Nada Hamid Majid and Ibtisam Magid Rashid, 2007, Assessment of Water quality wells for College of agriculture biologically and chemically and suitability for agricultural uses according to global 


\section{AL-Qadisiyah Journal of pure Science $\quad$ Vol.23 No.2 $\quad$ Year 2018}

drinking-water Quality. 4th ed

18. Fouad, S. F. 2007. "Tectonic and Structural Evolution of the Iraqi Western Desert." Geolo

21. Gilliam., Jalil Dhamad, 1997 , proposed manual for assessing the quality of irrigation water in Iraq. $\mathrm{PhD}$ thesis, Soil Department, Collage of agriculture, University of Basrah, $\mathrm{P}$ 138.
16. _World Health Organization (WHO) .2011. Guide lines for

17. Geneva. Pp.30-120.

19. gy of Iraqi Western Desert, Iraqi Bulletin of Geology and Mining 1: 29-50.

20. Fouad, S. F. 2012. Tectonic Map of Iraq, Scale 1:1,000,000. 3rd ed.. Baghdad: GEOSURV. 


AL-Qadisiyah Journal of pure Science $\quad$ Vol.23 No. $2 \quad$ Year 2018

WQ تقييم نوعية المياه الجوفية لبعض الآبار في غرب محافظة النجف باستخدام

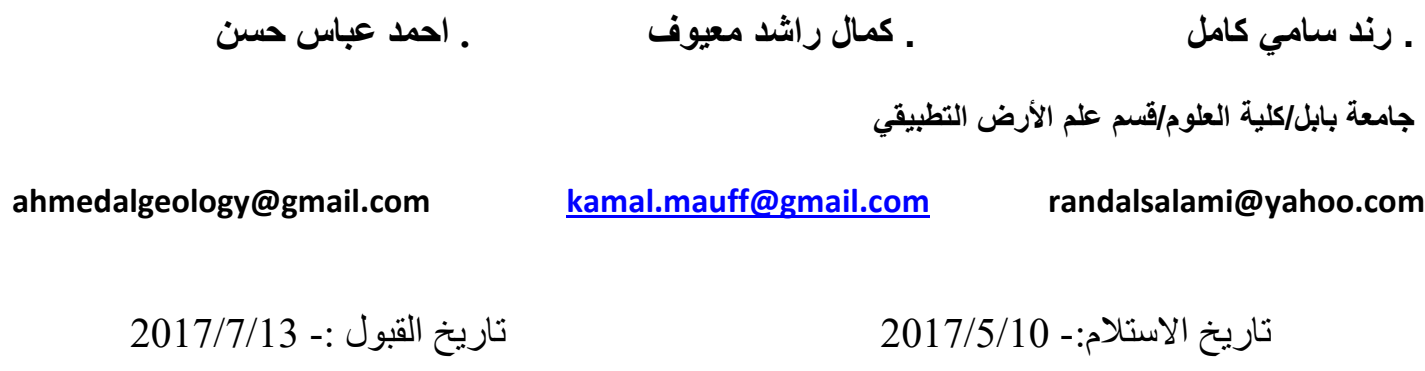

الخلاصة

تعتبر مدينة النجف من المدن الزراعية مدينة النجف أو النّجف الأشرف إحدى أبرز مدن العراق ومركز محافظة النجف، تقع إلى

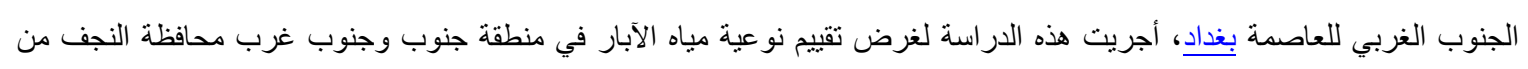
خلال أختيار 32 بئر موز عة في المنطقة وتحليل مياهها كيميائياً وفيزيائياً . وقد بينت النتائج وجود تغايرات في نوعية المياه بأختلاف مو اقعها تم أعتماد مواصفات منظمة الصحة العالمية WHO ومواصفات عراقية صادرة عن الجهاز المركزي للتقييس والسيطرة النوعية وبإستخدام دليل نو عية المياه WQI وجد بأن مياه هذه الآبار غير صالحة للشرب جميعا. اما من ناحية الاستخدام الحيو اني فكانت قيم TDS تتراوح بين (658-4570) هذا يعني ان المياه الجوفية في منطقة الدراسة كانت من نوع brackish water ماء مالح. وبالنسبة للري وجد بأن الأيصالية الكهربائية EC تراوحت بين (5,305-2,342) ديسيسيمنز.ج-1 في الآبار6، 7، 9، 12، 13، 14، 16، 17، 21، 22، 26، 26، 28، 30، 31، 32 حيث توجد زيادة واضحة في قيم التوصيلية الكهربائية. اذ تعتمد قيم التوصيل الكهربائي للمياه على تركيز ونو عية الأملاح فيها، كانت قيم SAR تتراوح بين (6.812-0.92)، لذلك فان تصنيف هذه الآبار حسب مواصفات منظمة الزراعة والاغذية (FAO,1989) لتحديد صلاحية مياه الري كانت كما يلي: كانت قيم TDS كبيرة جدا تجاوزت الحدود المسموحة فان الري بها خطر حسب المواصفة، تأثير نسبة امتزاز الصوديوم SAR مع التوصيلية الكهربائية ذات تأثير (قليل-متوسط) على ري المحاصيل الزراعية، قيم عنصر الصوديوم

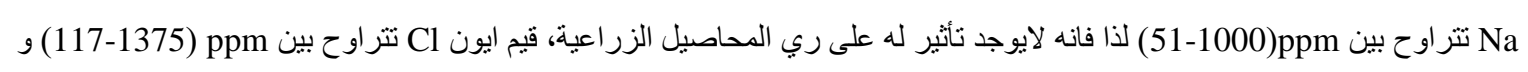
ابون البيكاربونات Nت NO3 No

$$
\text { الري بها لان نسبة }
$$

اما الآبار 2، 6، 9، 15، 18، 28، 32 فأن نسبة NO فيها كانت بين (30-5) و هذا فيه خطورة متوسطة_قليلة عند السقي بها. أما بقية الآبار فكانت $\mathrm{NO}_{3}$ فيها أقل من 0.5 لذلك لا توجد مشكلة عذد الري بها. الأس الهيدروجيني) تقع ضمن هذا المدى المسموح به

$$
\text { عدا الآبار رقم 22، 23، 32، كانت أقل من الحدود المسموح بها حسب المواصفة. }
$$


بعد الاطلاع على النتائج نستنتج ان المياه غير صالحة للثرب وتحتاج الى معالجات لاستخدامها للحيو ان ولري المحاصيل الزر اعية. الكلمات المفتاحية: WQI، المياة الجوفية ،ابار ، العوامل 